\title{
CONSIDERATIONS ON THE BENEFITS OF USING RECYCLABLE MATERIALS FOR ROAD CONSTRUCTION
}

Diana POPESCU, eng., Technical University of Civil Engineering Bucharest, Romania, e-mail: popescu.diana05@yahoo.com

Adrian BURLACU, phd., Technical University of Civil Engineering Bucharest, Romania, e-mail: adrian_burlacu@yahoo.com

\section{Rezumat}

O problemă actuală a economiei mondiale o constituie atât gestionarea responsabilă a resurselor neregenerabile ale planetei cât și gestionarea numeroaselor deșeuri rezultate în urma a diverse activități economice. Beneficiile aduse de utilizarea materialelor reciclabile împreună cu tehnologiile de reciclare a mixturilor asfaltice constau în principal în reducerea consumului de combustibil și a emisiilor de gaze cu efect de seră. Este un lucru bine știut că petrolul (din care se obține bitumul) este o resursă neregenerabilă, de unde și prețul său tot mai ridicat. De aceea, la ora actuală, pe plan mondial se caută soluții care să conducă la o buna utilizare a resurselor naturale, dar și de integrare în circuitul economic al unor subproduse din diverse industrii. Această lucrare dorește să aducă în prim plan soluțiile de reciclare a mixturilor asfaltice, precum și materialele reciclabile care pot fi folosite ca adaosuri, împreună cu beneficiile fiecăruia.

Cuvinte cheie: reciclare, încălzire globală, zgură, pudreta de cauciuc, plastic

\section{Abstract}

A current worldwide economy problem includes both the responsible management of the planet's non-renewable resources and the waste management. The benefits of using recyclable materials and recycling technologies with asphalt mixtures consist mainly of reducing fuel consumption and greenhouse gas emissions. It is well known that oil (from which bitumen is obtained) is a non-renewable resource, hence the its price increase. Therefore, at present, the world is looking for solutions that will lead to a better use of natural resources and to an economic integration of sub- products from various industries. This paper intends to raise awareness of the possibilities for asphalt mixtures recycling and of the recyclable materials that can be used as additives with benefits of each.

Keywords: recycling, global warming, slag, crumb rubber, plastic 


\section{INTRODUCTION}

There are over 65 million kilometers of roads and motorways in the world, of which several hundred thousand require important rehabilitation works every year. Governments and local authorities everywhere allocate approximately $\$ 100$ billion annually to try to keep functional and safe road traffic. Even under these conditions, there are a significant number of damaged roads due to the inadequate budgets allocated for transport and the high costs imposed by traditional rehabilitation methods.

The European Asphalt Pavement Association (EAPA) provides worldwide statistical data on how recycled asphalt is used:

Table 1. Recycling worldwide

\begin{tabular}{|c|c|c|c|c|c|c|}
\hline \multirow[t]{2}{*}{ Country } & \multirow{2}{*}{$\begin{array}{l}\text { Available reclaimed } \\
\text { asphalt (tonnes) }\end{array}$} & \multicolumn{4}{|c|}{$\%$ of available reclaimed asphalt used in } & \multirow{2}{*}{$\begin{array}{l}\% \text { of the new hot and warm } \\
\text { mix production that } \\
\text { contains reclaimed } \\
\text { material }\end{array}$} \\
\hline & & $\begin{array}{l}\text { hot and warm } \\
\text { recycling }\end{array}$ & half warm recycling & cold recycling & unbound layers & \\
\hline Austrio & 750.000 & 95 & & 3 & 2 & \\
\hline Belgium & 1.500 .000 & 61 & No data & No dato & No dato & 51 \\
\hline Czech Republic & 1.450 .000 & 18 & 0 & 25 & 20 & 10 \\
\hline Denmork & 790.000 & 83 & & & 17 & 58 \\
\hline Finland & 860.000 & & & & & 20 \\
\hline France & 6.900 .000 & 64 & No data & No dato & No dato & $>65$ \\
\hline Germany & 11.500 .000 & 90 & & & 10 & No data \\
\hline Greece & No dato & & & & & 0,03 \\
\hline Great Britain & $4.000 .000-5.000 .000$ & & & & & \\
\hline Hungary & 88.000 & 80 & 0 & 10 & 10 & 20 \\
\hline iceland & 15.000 & & & & & 3,0 \\
\hline Ireland & 150.000 & & & & & \\
\hline liraly & 10.000 .000 & 20 & & & & \\
\hline Luxembourg & 300.000 & 90 & 0 & 10 & 0 & 50 \\
\hline Netherlands & 4.500 .000 & 76 & & & & 70 \\
\hline Norway & 686.268 & 21 & 0 & 5 & 74 & 20 \\
\hline Romania & 22.000 & 20 & 20 & 20 & 30 & 10 \\
\hline Slovakia & 26.000 & 90 & 0 & 5 & 5 & \\
\hline Slovenia & 26.000 & 26 & 0 & 20 & 54 & 5 \\
\hline Spain & 205.000 & 85 & & 7 & 8 & 1,3 \\
\hline Sweden & 900.000 & 80 & 5 & 5 & 10 & 70 \\
\hline Switzerland & 1.370 .000 & 48 & 17 & 15 & 8 & 27 \\
\hline Turkey & 1.200 .000 & 3 & & 1 & 96 & 1 \\
\hline
\end{tabular}

\begin{tabular}{|l|r|r|r|r|r|}
\hline Japan & & & & & 76 \\
\hline U.S.A. & 69.000 .000 & 92 & & 8 & 8 \\
\hline
\end{tabular}

Damaged road asphalt is characterized by poor operating quality and physical degradation, such as cracks, rutting and slippery rolling surfaces. The process of damaging road asphalt is accelerating after a few years of operation, but early rehabilitation by new bedding or recycling can restore the quality of road asphalt and thus extend the life of that road.

World Bank studies have shown that recycling road asphalt is particularly cost-effective, especially when it is executed before the damage reaches an extremely advanced stage: based on their studies, it is very important to perform the rehabilitation (recycling, new bedding) when the degradation state has 
worsened by about $40 \%$ relative to the initial state, or else, for each dollar that would have been used for rehabilitation at $40 \%$, four or five dollars could be used when the degradation state has worsened by $80 \%$.

\section{ROAD RECYCLING TECHNOLOGIES}

\subsection{Hot-in-place recycling}

Hot in-place recycling is a rehabilitation process for degraded road asphalt. The operation is entirely carried out by a machine assembly (recycler train) and begins by applying heat to "soften" the rolling layer of road asphalt. The softened asphalt material is removed by milling devices and subsequently mixed with or without the addition of any recycling agent. The recycled asphalt mix is then laid along the road and compacted to complete the recycling process. Although this recycling-based method is $100 \%$ absolutely efficient, some remixing options such as the addition of new hot asphalt mix or new mineral aggregates may be necessary for structural correction and improvement of the geometric elements of the road.

The old, old, defective surface is replaced by a new layer, which ensures the elimination of the irregularities both in the longitudinal and transversal plane Advantages of this method:

- removal of cracks and other surface defects;

- reuse of existing materials;

- in turn, the recycled mix can be recycled again;

- minimizes traffic jams - only work on a lane, others can remain open to traffic;

- preserving the existing road geometry.

The asphalt layer made from hot recycled asphalt mix has generally as good performance, if not better, as the asphalt layer produced by traditional methods.

\subsection{Cold-in-place recycling}

Using the cold-in-place recycling with the addition of bituminous and hydraulic binders, a durable base layer is obtained by reusing the existing material, the loss of the material being zero. Adjacent binders will be established either by designers or by specialized laboratories. Binders can be: different types of cement, hot bitumen, bituminous emulsion, lime.

Advantages of this method:

- the process is one that protects the environment; 
- reuse of the material from the old asphalt structure with a minimum intake of new material;

- is considered the most economical way to rehabilitate the road;

- low cost because it can be done without the addition of granular materials.

\section{TYPES OF MATERIALS THAT CAN BE USED AS ADDITIVES FOR RECYCLING IN ROAD WORKS}

\subsection{Slag}

The first experiences in using slag as aggregate in asphalt mixes date back to 1969 when an experimental road section was built in Toronto. Within this section, the slag was used both as an aggregate in the base layer and in the wear layer $[1,2]$. The studied asphalt mixes have demonstrated very good properties in terms of bearing capacity, resistance to external factors and durability.

Emery $[2,3]$ points out that in the first use of slag in asphalt mixes there were situations where the layers put into operation exhibited premature cracks and permanent deformations, which were later related to the lack of stability of the slag due to free oxides calcium and magnesium. The reasons were not a very careful selection of the materials and the inappropriate kneading method.

Confirmation of the possibility of using this residual material in asphalt mixtures was provided by the research done at McMaster University [1, 2], which showed that the elastic moduli of asphalt mixtures with slag are higher by $20-80 \%$ than those with aggregates.

Slag generated as a by-product resulting from the steel and iron production process can be broadly classified as blast furnace slag and steel slag. Blast furnace slag is a by-product of iron production in furnace and is mainly composed of silicates and limestone-silicates of limestone or other basic substances. Depending on the cooling method used, it is classified either as "airborne" slag or granular slag, rapidly cooled by immersion in water.

Due to its rough shape, hardness and texture, steel slag can be used as a substitute for aggregates in places where the stability of the mix and the roughness of the tread surface have to meet increased requirements. Because steel slag has the ability to retain heat longer than normal aggregates, the temperature of the mix when put into operation can be reduced, resulting in lower energy consumption.

The research study presented in [14] leads to the same conclusions: an alternative to natural aggregate is blast furnace slag which lead to a good behavior of asphalt mixture, as it results from laboratory studies despite poor slag characteristics. 


\subsection{Rubber powder}

Bitumen with rubber powder is a mixture of hot bitumen and ground rubber coming from waste or scrap. It is widely used in the transport industry both in Europe and the USA.

At present, waste from used tires may be used in two ways: mixing powder rubber in bitumen and subsequent use as modified bitumen with rubber powder or by replacing a fine part of aggregates (usually 1-3\%) with this rubber powder. In the wet process, by mixing 5-12\% at bitumen the weight of the rubber powder (dimensions $0.15-0.6 \mathrm{~mm}$ ) with the bitumen for at least 45 minutes at a high temperature prior to contact with the aggregates, the viscosity of the binder increases and influences positive and its thermal susceptibility.

The result of this mixture can be influenced by a number of factors such as the bitumen composition, the mixing time and temperature, the percentage and degree of grinding of the rubber, and the mixing method $[4,5]$. From the point of view of the layered asphalt mix layer, the thickness of the layer can be up to $20-25 \%$ thinner without affecting the performance of the layer, as confirmed by a study at the University of California at Berkeley [6]. Also, a study in Brazil showed that due to a $15 \%$ addition of rubber powder in the asphalt mix layer, cracks propagate 5-6 times slower than normal asphalt mix.

Using asphalt mixtures with additives such as rubber, there are produces asphalt mixtures usable in the wearing course, with good exploitation behavior, with a long lifetime, with low maintenance costs, all in the context of environmental protection, due to the use of WMA technology and the reduction of used tires deposits $[13,15]$.

In terms of noise, the Rubber Pavements Association (RPA) said the use of rubber in open asphalt mixes reduces noise by up to $50 \%$.

\subsection{Glass}

Today's modern consumer society has been found face to face with an increasingly common problem: finding use for the ever-increasing quantities of glass for which the only option was storage at a warehouse of waste. At the same time, asphalt mixers are looking for a quality replacement of the aggregates, thus opening up a new opportunity: a 10: 1 mixture of aggregates and glass was sent to the Minnesota Department of Transportation Tests (Mn / DOT). The Mn / DOT results have shown that adding the glass helps to increase the quality of this blend. After this first test, the Minnesota State initiated a new project: an experimental section of about $400 \mathrm{~m}$, which demonstrated the 
advantages of using glass as a replacement for a percentage of aggregate and convinced other states of its benefits.

Currently, in the U.S., up to $10 \%$ of glass may be used instead of aggregates in the core layers. The maximum glass size should be $4.75 \mathrm{~mm}$ due to safety measures, but also because a large glass surface will not have the proper roughness. The best results were obtained when the glass content was at most $10 \%$ of the total weight and the glass size was less than $6 \mathrm{~mm}$.

\subsection{Plastic}

Approximately 2.8 million tons of plastic wastes are generated per year in the UK. Data provided by WRAP UK shows that out of the 2.8 million tons, only 0.4 million are suitable for use in transport. At present only 0.008 million tons are recycled for this purpose. Recycled plastic materials are mainly used in the form of street furniture, insulation, pipes and pipes, etc. and less in the field of road construction [7].

Recycled plastics can replace either a percentage of aggregates or serve as a bitumen modifier. Studies in the United Kingdom on asphalt mixtures containing recycled plastics, mainly Low Density Polyethylene (LDPE), which replace about $30 \%$ of the $2.36-5 \mathrm{~mm}$ aggregates, show a number of advantages such as increasing Marshall's stability and increased tensile strength. The major advantage is that no modification of existing installations for mixing recycled LDPE with asphalt mix [5] is required in the manufacturing process.

\subsection{Crushed concrete}

The American Concrete Pavement Association estimates that approximately 322 kilometers of concrete road is recycled each year and that about 1750 tons of crushed concrete can be recovered from a $1.0 \mathrm{~km}$ concrete road with an average thickness of $25 \mathrm{~cm}$. This shows that 2.6 million tons of concrete is recycled annually in the United States.

Concrete from roads, pavements, buildings, as well as from other sources can be crushed for reuse. It is recommended that reinforcements or other embedded materials be removed before crushing the concrete. Concrete crushing produces granular aggregates, hard, composed of inert minerals such as sand, gravel or crushed stone. Due to the adhesion of cement mortar to aggregates incorporated in concrete, aggregates resulting from concrete crushing have a hard texture, low apparent density, and water absorption is higher than natural aggregates compared in size. If the size of aggregates resulting from crushing 
the concrete is lower, there is a decrease in apparent density and an increase in water absorption.

\section{EFFECTS ON THE ENVIRONMENT}

Road construction requires a significant amount of non-renewable materials and energy. The large dimension of energy investments, but not only, shows that there is a need for a better understanding of the economic and environmental aspects of using virgin materials versus recycled materials. Even if there are clear benefits of using recycled materials such as shutting down river bed aggregates or reducing the number of landfills, the use of these materials depends on other factors and indicators used to analyze the quality of the finished product. Also, the production and transport process play an important role in demonstrating the desirability of such an investment.

Concerns about the impact that the use of these recycled materials has on the environment relate to the possibility that certain constituents may infiltrate the soil and the groundwater and become dangerous to the environment and human health. The effects that the processing and transport of these secondary materials are also taken into consideration. Thus, the possibility of using these products has to be assessed according to the potential effects they will have on the environment compared to traditional materials. For example, the energy required to recycle materials resulting from the demolition of civilian or even road construction may be higher than the energy consumed for processing, transporting and depositing an asphalt mix with classical materials.

Several studies have investigated the impact of using recycled asphalt mix (RAP). The Athena Institute found that when using 20\% of RAP in the asphalt mix, there was a reduction in global warming and global warming potential (GWP-Global Warming Potential) of about $7.5 \%$ to $13 \%$, taking into account a life cycle of 50 years [8]. Case studies by Huang et al. reported that the use of $25 \%$ RAP and $10 \%$ of fly ash contributed to a $4 \%$ reduction in total energy consumed for the production and layout of the mix as well as $\mathrm{CO} 2$ emissions [9]. Another study by Aurangzeb et al. found that the use of 30\%, 40\%, and 50\% of RAPs decreased energy and $\mathrm{CO} 2$ consumption by $7.3 \%, 9.8 \%$ and $12.2 \%$, respectively, compared to the situation where the PAP was not used [10]. Finally, a recent study by the US Environmental Protection Agency (US EPA) reported that using $25 \%$ of RAPs reduced greenhouse gas emissions by up to $16 \%$, highlighting the importance of use of recycled materials.

The degree of saving of total energy consumption and greenhouse gas emissions differs from project to project because each study is based on different assumptions. However, literature studies have consistently shown that the use of 
recycled materials, such as RAP, can bring benefits to the environment as long as road performance is not compromised.

\section{ECONOMIC ISSUES THAT MUST BE TAKEN INTO CONSIDERATION}

Significant savings can be made by using recycled asphalt mix. Their size depends on the chosen recycling technology, as well as the quality of the materials put into work. First, savings can be made due to the use of recycled materials: aggregates, bitumen, etc. Also, by using substitutes for aggregates such as those listed above, landfills are shrinking and therefore the money spent on renting such places will be less. In most cases, the energy consumed for recycling a road is less than that needed to produce, transport and deposit a new layer of new asphalt mix.

Other advantages can be obtained by the fact that the process is carried out in most cases in-site, thus reducing the transport costs and implicitly the energy consumed for transporting the aggregates at the mixing station and then transporting the mixture to the site.

However, in order to highlight the advantages of using recyclable materials in road construction, several factors have to be taken into account: for example, even if material transport costs can be reduced, this cannot be the determining factor in choosing asphalt recycling over a new traditional asphalt layer. In the USA, cement production costs $\$ 100 /$ ton, while the costs of producing fly ash can reach $\$ 90$ / ton. [11] In this case, the difference between the two is not significant and the subsequent costs of using fly ash can be even higher than if traditional cement was used.

In a 1998 publication of the Federal Highway Administration [12], the authors estimate a lower cost of $\$ 8.20$ per ton for recycled asphalt mix compared to a tons of classical asphalt mix.

\section{ESTIMATION OF $\mathrm{CO}_{2}$ EMISSIONS FOR DIFFERENT TYPES OF ASPHALTIC MIXTURES WITH "asPECT" SOFTWARE}

With the aid of "asPECT" program (asphalt Pavement Embodied Carbon Tool), a software developed by the Transport Research Laboratory in the UK, we attempted a comparison between 6 types of asphalt mixtures, conventional and modern mixtures alike, from the point of view of $\mathrm{CO}_{2}$ emissions.

To perform the analysis, we used materials from the material base of the program and materials introduced on the basis of $\mathrm{CO}_{2 \mathrm{e}}$ emissions. To obtain a relevant $\mathrm{CO}_{2 \mathrm{e}}$ value we have taken into consideration a number of processes 


\section{ROMANIAN JOURNAL OF TRANSPORT INFRASTRUCTURE}

such as: the processing (and reprocessing of the materials if they are recycled), the transport from the warehouse to the asphalt mix plant and then at the site, the transport distance being the same for all analyzed asphalt mixes: $25 \mathrm{~km}$.

The asphalt mixtures that we studied are:

- classic asphalt mix without additives;

- polymer modified bitumen asphalt mixture;

- fiber stabilized asphalt mixture;

- asphalt mixture with glass addition;

- asphalt mixture with addition of furnace slag;

- asphalt mixture with added rubber powder.

The results are the following:

Table 2. Comparative analysis results

\begin{tabular}{|c|c|c|c|c|c|c|}
\hline & $\begin{array}{c}\text { Extraction } \\
\text { and } \\
\text { processing } \\
\text { of the } \\
\text { materials } \\
\left.\mathrm{kgCO}_{2 \mathrm{e}} / \mathrm{m}^{3}\right)\end{array}$ & $\begin{array}{c}\text { Transport to } \\
\text { the asphalt } \\
\text { mixture } \\
\text { plant } \\
\left(\mathrm{kgCO}_{2 \mathrm{e}} / \mathrm{m}^{3}\right)\end{array}$ & $\begin{array}{c}\text { Asphalt mix } \\
\text { preparation } \\
\left(\mathrm{kgCO}_{2 \mathrm{e}} / \mathrm{m}^{3}\right)\end{array}$ & $\begin{array}{c}\text { Transport to } \\
\text { the site } \\
\left.\mathrm{kgCO}_{2 \mathrm{e}} / \mathrm{m}^{3}\right)\end{array}$ & $\begin{array}{c}\text { Laying and } \\
\text { compaction } \\
\left(\mathrm{kgCO}_{2 \mathrm{e}} / \mathrm{m}^{3}\right)\end{array}$ & $\begin{array}{c}\text { Total } \\
\left(\mathrm{kgCO}_{2 \mathrm{e}} / \mathrm{m}^{3}\right)\end{array}$ \\
\hline $\begin{array}{c}\text { Asphalt } \\
\text { mix 1 }\end{array}$ & 16.65 & 15.79 & 22.94 & 15.09 & 4.70 & 75.17 \\
\hline $\begin{array}{c}\text { Asphalt } \\
\text { mix 2 }\end{array}$ & 24.75 & 15.79 & 22.94 & 15.09 & 4.70 & 85.97 \\
\hline $\begin{array}{c}\text { Asphalt } \\
\text { mix 3 }\end{array}$ & 16.62 & 15.79 & 22.94 & 15.09 & 4.70 & 75.14 \\
\hline $\begin{array}{c}\text { Asphalt } \\
\text { mix a 4 }\end{array}$ & 16.80 & 15.72 & 22.94 & 15.09 & 4.70 & 75.25 \\
\hline $\begin{array}{c}\text { Asphalt } \\
\text { mix a 5 }\end{array}$ & 22.20 & 15.72 & 22.94 & 15.09 & 4.70 & 80.65 \\
\hline $\begin{array}{c}\text { Asphalt } \\
\text { mix 6 }\end{array}$ & 16.70 & 15.79 & 22.94 & 15.09 & 4.70 & 75.22 \\
\hline
\end{tabular}

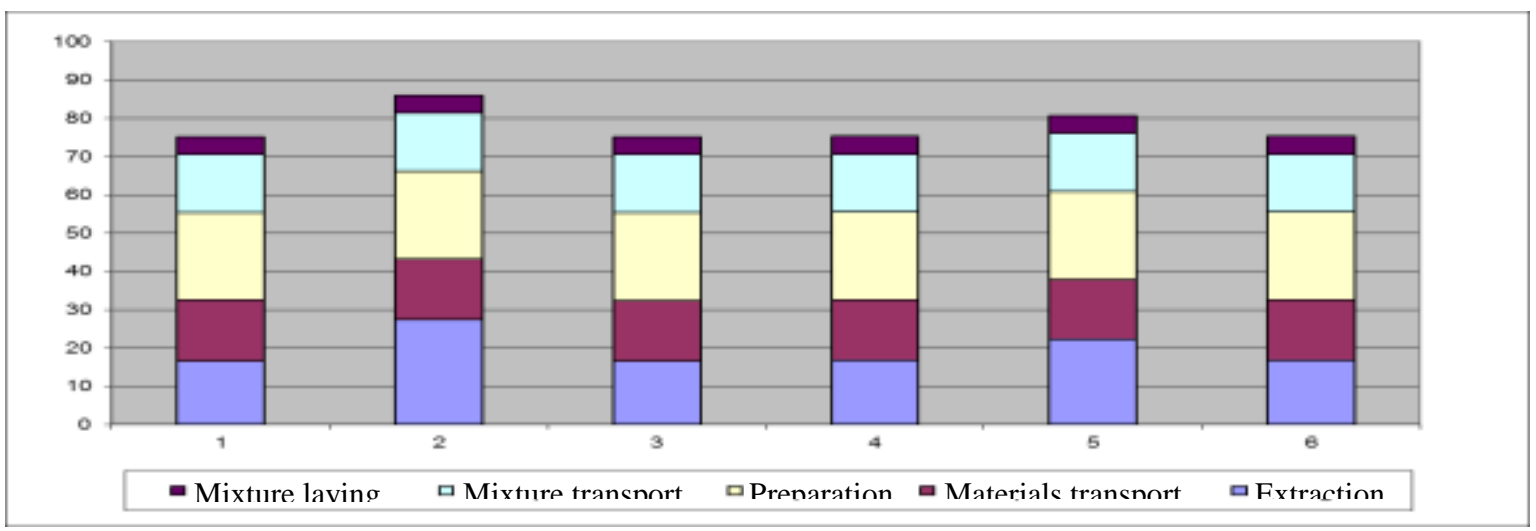

Figure 1. Comparison between the 6 types of asphalt mix 


\section{CONCLUSIONS}

In a century where there is more and more talk about recycling, responsible consumption and efficiency, the field of transport infrastructure should reflect these concepts.

From the data provided by the EAPA, it can be noticed how smaller countries than Romania, such as Belgium or the Czech Republic, recycle almost 66 times more than our country, a worrying fact given the economic and technical benefits that may result from recycling of the existing mix or integration into the original recipe of unconventional additives that have proven their advantages over time.

Regarding environmental effects, the study done with the program "asPECT" represents only a small part of this analysis. Table 2 shows how asphalt mixes with polymer modified bitumen and those with granular furnace slag would be the most environmentally damaging, but the many factors that could come into such analysis could not be integrated into the program "asPECT".

So, at a time when technology is constantly developing, maybe it is time for transport infrastructure to join this eco-trend.

\section{REFERENCES}

[1]. J.J.EMERY: "Slag utilization in pavement construction. // Extending aggregate resources", in "American Society for Testing and Materials", pg. 95-119, 1982.

[2]. J.J.EMERY: "Steel slag utilization in asphalt mixes", www.nationalslagassoc.org

[3]. "User guidelines for byproducts and secondary use materials in pavement construction. Steel slag". www.rmrc.unh.edu/tools/uguidelines/ssa2.asp

[4]. R.C. WEST, G.C. PAGE, J. VEILLEUX: "Effect of tyre rubber grinding method on asphalt-rubber binder characteristics", in "Proceedings of the Transport Research Board Annual Meeting", 1998.

[5]. W.H.CHESNER, R.J.COLLINS, M.H.MACKAY: "User Guidelines for Waste and By-Product Materials in Pavement Construction", nr. FHWA-RD-97-148, April 1998.

[6]. R.G.HICKS: "Asphalt rubber design and construction guidelines - volume 1- design guidelines", 2002. 


\section{ROMANIAN JOURNAL OF TRANSPORT INFRASTRUCTURE}

Diana Popescu, Adrian Burlacu

Considerations on the benefits of using recyclable materials for road construction

[7]. WRAP: "AggRegain materials information - recycled plastics", 2003.

[8]. J.MELI: "A Life Cycle Perspective on Concrete and Asphalt Roadways: Embodied Primary Energy and Global Warming Potential", Athena Institute, Ottawa, Ontario, Canada, 2006.

[9]. Y.HUANG, R. BIRD, O. HEIDRICH: "Development of a life cycle assessment tool for construction and maintenance of asphalt pavements", in "Journal of Cleaner Production", volume 17, no. 2, 2009.

[10]. Q.AURANGZEB, I. L. AL-QADI, H. OZER, R. YANG: "Hybrid life cycle assessment for asphalt mixtures with high RAP content.", in "Resources, Conservation and Recycling", volume 83, 2013.

[11]. V.M. MALHOTRA: "Fly ash, slag, silica fume, and rice-husk ash in concrete: a review", in "Concrete International", April 1993.

[12]. P.S.KANDHAL, R.B.MALLICK: "Pavement recycling guidelines for state and local governments ", no. FHWA-SA-98-042, December 1997.

[13]. C. RĂCĂNEL, A. BURLACU, “Using crumb rubber in warm asphalt concrete”, $15^{\text {th }}$ „International Multidisciplinary Scientific Geo Conference SGEM Albena, Bulgaria, 18 - 24 june 2015, ISBN 978-619-7105-38-4, ISSN 1314-2704, DOI: 10.5593/sgem2015B41, 2015

[14]. C. RĂCĂNEL, Ş. LAZĂR, C. PETCU, "Asphalt mixtures with blast furnace slag performances using “warm mix” technology”, $17^{\text {th }}$ „International Multidisciplinary Scientific Geo Conference SGEM Albena, Bulgaria, 29 june - 5 july 2017 ISBN 978619-7408-06-5, ISSN 1314-2704, DOI: 10.5593/sgem2017/41, 2017

[15]. C. RĂCĂNEL, A.G. TĂNĂSESCU, M.G. TOMA, "Using additives in asphalt mixtures for better roads in term of recycling”, $17^{\text {th }}$ „International Multidisciplinary Scientific Geo Conference SGEM Albena, Bulgaria, 29 june - 5 july 2017 ISBN 978619-7408-06-5, ISSN 1314-2704, DOI: 10.5593/sgem2017/41, 2017 